\title{
PENGARUH EFEKTIVITAS PELAYANAN AKADEMIK DAN KOMPETENSI PEDAGOGIK GURU TERHADAP MINAT BELAJAR SISWA SEKOLAH MENENGAH PERTAMA NEGERI DI KECAMATAN JATIBARANG KABUPATEN INDRAMAYU
}

\section{Ratnaningrum \\ SMP Negeri 2 Jatibarang Indramayu-Jawa Barat, Email:ratnaningrum2521965@gmail.com}

Received January 18, 2020, reviewed March 28, 2020, published Apr 30, 2020

Citation: Ratnaningrum. (2020). Pengaruh Efektivitas Pelayanan Akademik dan Kompetensi Pedagogik Guru Terhadap Minat Belajar Siswa Sekolah Menengah Pertama Negeri Di Kecamatan Jatibarang Kabupaten Indramayu. Edum Journal, 3(1)

\begin{abstract}
ABSTRAK
Tujuan penelitian ini adalah mengetahui pengaruh pelayanan akademik dan kopetensi pedagogik guru terhadap minat belajar siswa. Penelitian ini merupakan penelitian kualitatif menggunakan metode quasi eksperimen, disertai dengan teknik pengumpulan data menggunakan angket skala Likert terhadap 52 orang guru sekolah menengah pertama (SMP) Negeri di Kecamatan Jatibarang Kabupaten Indramayu. Pengolahan hasil penelitian menggunakan teknik analisis regresi. Uji signifikansi menggunakan uji-F. Hasil penelitian menunjukkan bahwa: (1) Terdapat pengaruh positif dan signifikan efektivitas pelayanan akademik terhadap minat belajar siswa SMP Negeri di Kecamatan Jatibarang Kabupaten Indramayu. (2) Terdapat pengaruh positif dan signifikan kompetensi pedagogik guru terhadap minat belajar siswa SMP Negeri di Kecamatan Jatibarang Kabupaten Indramayu. (3) Terdapat pengaruh positif dan signifikan efektivitas pelayanan akademik dan kompetensi pedagogik guru secara simultan terhadap minat belajar siswa SMP Negeri di Kecamatan Jatibarang Kabupaten Indramayu. Bertolak dari kondisi tersebut penulis menyarankan: (1) Hasil penelitian menunjukkan bahwa pelayanan akademik sudah efektif, tetapi karena berpengaruh terhadap minat belajar siswa maka masih ada sisi yang dapat dikembangkan yaitu yang berkaitan dengan kelengkapan instrumen berikut pendayagunaannya melalui perbaikan manajemen sarana dan prasarana. (2) Berdasarkan hasil penelitian, secara umum kompetensi pedagogik guru sudah bagus. Tetapi untuk lebih memaksimalkan minat belajar siswa, sebaiknya kepala sekolah dan guru lebih fokus pada pemahaman tentang siswa (peserta didik) agar lebih mudah mengarahkannya.
\end{abstract}

Kata Kunci: Efektivitas Pelayanan, Kompetensi Pedagogik, Minat Belajar

\begin{abstract}
The purpose of this research is to determine the effect of academic services and teacher pedagogical competence on student interest in learning. This research ia a qualitative research using quaiexperimental methods, accompanied by data collection techniques using a Likert scale questionnaire of 52 teachers of state junior high schools in Jatibarang District, Indramayu Regency. Processing of research results using regression analysis techniques. The significance test uses the F-test. The results showed that: (1) There was a positive and significant effect on the effectiveness of academic services on the learning interest of students of state junior high schools in Jatibarang District, Indramayu Regency. (2) There is a positive and significant influence of teacher's pedagogical competence on students' interest in learning at state junior high schools in Jatibarang District, Indramayu Regency. (3) There is a positive and significant effect of the effectiveness of academic services and simultaneous pedagogical competence of teachers on the learning interest of students of State Junior High Schools in Jatibarang District, Indramayu Regency. Departing from these conditions the authors suggest: (1) The results of the study indicate that academic services have been effective, but because they affect student interest in learning, there is still a side that can be developed that is related to the completeness of instruments and their utilization through improved management of facilities and infrastructure. (2) Based on the results of the study, in general the pedagogical competence of
\end{abstract}


teachers is already good. But to further maximize student interest in learning, school principals and teachers should focus more on understanding students (students) to make it easier to direct them.

Keywords: Service Effectiveness, Pedagogical Competence, Learning Interest

\section{PENDAHULUAN}

Berkaitan dengan minat belajar ini, penulis mencoba mengadakan observasi selayang pandang kepada siswa sekolah menengah pertama (SMP) Negeri di Kecamatan Jatibarang Kabupaten Indramayu. Pada tahap awal ditemui ragam fenomena yang mengemuka di antaranya: (1) Hampir sepertiga siswa kurang senang dengan pembelajaran yang dilaksanakan di sekolah mereka; (2) Masih banyak siswa yang kurang tertarik terhadap pelajaran sehingga cenderung kurang minat belajar; (3) Aktivitas belajar masih belum maksimal sehingga cenderung kurang membiasakan siswa untuk belajar; (4) Terdapat kecenderungan siswa kurang aktif dalam pembelajaran yang dimunghkinkan oleh kurangnya minat belajar; (5) Masih sekitar $15 \%$ siswa kuarng menyadari aspek fungsional pelajaran terhadap masa depan mereka; (6) Proses pembelajaran kurang mendorong atau kurang mempengaruhi siswa untuk berubah perilakunya.

Pelayanan akademik di antaranya menyangkut: daftar ulang, perizinan, akses nilai, bimbingan dan konseling, kompensasi, jadwal pembelajaran, evaluasi ujian tengah dan akhir semester, pelaksanaan praktikum dan studi lapangan (kalau ada). Sedangkan pelayanan non akademik merupakan pelayanan terhadap siswa selain hal yang berkaitan dengan proses dan hasil pembelajaran. Misalnya, kondisi toilet dan ruang belajar yang bersih, keamanan di sekolah dengan adanya Satpam, penyambutan yang wajar dan keramahan ketika orang tua siswa ada keperluan dengan pihak sekolah, dan lain sebagainya.

Sebagai suatu sistem pelayanan akademik, tujuan utamanya bukan hanya kepuasan pelanggan. Lebih dari itu perlu dilihat kebermanfaatan untuk lembaga menyangkut keberlangsungannya.
Dengan kata lain bahwa pelayanan akademik harus selalu ada perbaikan dengan tidak mengesampingkan faktor pengelolaan yang benar sehingga menghasilkan pelayanan yang bagus dengan operasional yang efektif. Tidak tertutup kemungkinan pelayanan akademiknya dapat menyenangkan dan memuaskan pelanggannya tetapi dilihat dari sisi operasional kelembagaan kurang efektif.

Selain efektivitas pelayanan akademik, faktor berikutnya yang turut menumbuhkembangkan minat belajar siswa adalah kompetensi pedagogik guru. Tentunya sepakat bahwa demikian pentingnya kompetensi pedagogik yang harus dimiliki oleh guru. Karena selain untuk memenuhi tuntutan undang-undang, lebih dari itu menaruh harapan besar agar mutu pendidikan selalu meningkat dari waktu ke waktu seiring dengan dinamika kebutuhan di masyarakat. Asumsinya adalah bahwa salah satu pendukung bagusnya atau meningkatnya mutu pendidikan adalah tergantung pada proses pembelajaran. Sehingga apabila mutu pembelajarannya bagus cenderung mutu pendidikannya juga akan bagus. Pada sisi lain salah satu aspek pendukung bagusnya mutu pembelajaran tergantung pada yang mengajar yaitu guru sebagai subyek utama. Oleh karena itu, kompetensi pedagogik diduga memiliki hubungan yang signifikan dengan mutu pembelajaran dan minat belajar siswa. Kompetensi, menurut Undang-undang Nomor 14 Tahun 2005 tentang Guru dan Dosen, adalah seperangkat pengetahuan, keterampilan, dan perilaku yang harus dimiliki, dihayati, dan dikuasai oleh guru atau dosen dalam melaksanakan tugas keprofesionalan. 


\section{EFEKTIVITAS \\ AKADEMIK, \\ PELAYANAN \\ PEDAGOGIK GURU DAN MINAT BELAJAR PESERTA DIDIK}

Dalam kamus besar Bahasa In

donesia indikator adalah Alat pemantau (sesuatu) yang dapat memberikan petunjuk/keterangan (Depdikbud, 1991). Kaitannya dengan minat siswa maka indikator adalah sebagai alat pemantau yang dapat memberikan petunjuk ke arah minat. Ada beberapa indikator siswa yang memiliki minat belajar yang tinggi hal ini dapat dikenali melalui proses belajar dikelas maupun dirumah. (1). Perasaan Senang. Seorang siswa yang memiliki perasaan senang atau suka terhadap pelajaran biologi misalnya, maka ia harus terus mempelajari ilmu yang berhubungan dengan biologi. Sama sekali tidak ada perasaan terpaksa untuk mempelajari bidang tersebut. (2) Perhatian dalam Belajar. Adanya perhatian juga menjadi salah satu indikator minat. Perhatian merupakan konsentrasi atau aktifitas jiwa kita terhadap pengamatan, pengertian, dan sebagainya dengan mengesampingkan yang lain dari pada itu. Seseorang yang memiliki minat pada objek tertentu maka dengan sendirinya dia akan memperhatikan objek tersebut. Misalnya, seorang siswa menaruh minat terhadap pelajaran biologi, maka ia berusaha untuk memperhatikan penjelasan dari gurunya. (3) Bahan Pelajaran dan Sikap Guru yang Menarik. Tidak semua siswa menyukai suatu bidang studi pelajaran karena faktor minatnya sendiri. Ada yang mengembangkan minatnya terhadap bidang pelajaran tersebut karena pengaruh dari gurunya, teman sekelas, bahan pelajaran yang menarik. Walaupun demikian lamakelamaan jika siswa mampu mengembangkan minatnya yang kuat terhadap mata pelajaran niscaya ia bisa memperoleh prestasi yang berhasil sekalipun ia tergolong siswa yang berkemampuan rata-rata. (4) Manfaat dan Fungsi Mata Pelajaran. Selain adanya perasaan senang, perh atian dalam belajar dan juga bahan pelajaran serta sikap guru yang menarik. Adanya manfaat dan fungsi dari pelajaran bagi dirinya juga merupakan salah satu indikator minat. Karena setiap pelajaran mempunyai manfaat dan fungsinya.

Ketertarikan terhadap cara guru mengajar merupakan cikal bakal ketertarikan siswa terhadap mata pelajaran yang disampaikan oleh guru tersebut. Sebagaimana kata Brown yang dikutip oleh Ali Imran (1996) bahwa: "Tertarik kepada guru, artinya tid ak membenci atau bersikap acuh tak acuh, tertarik kepada mata pelajaran yang diajarkan, mempunyai antusias yang tinggi sert a mengendalikan perhatiannya terutama kepada guru, ingin selalu ber gabung dalam kelompok kelas, ingin identitas dirinya diketahui oleh orng lain, tindakan kebiasaan dan moralnya selalu dalam kontroldiri, $\mathrm{s}$ elalu mengingat pelajaran dan mempelajarinya kembali, dan selal u terkontrol oleh lingkungannya"

Adapun makna belajar adalah "suatu proses usaha yang dilakukan seseorang untuk memperoleh suatu perubahan tingkah laku yang baru secara keseluruhan, sebagai hasil pengalamannya sendiri dalam interaksi dengan lingkungannya" Slameto (2003:2). Secara sederhana dari pengertian belajar sebagaimana yang dikemukakan oleh pendapat di atas, dapat diambil suatu pemahaman tentang hakekat dari aktivitas belajar adalah suatu perubahan yang terjadi dalam diri individu.

Minat besar pengaruhnya terhadap aktivitas belajar siswa, siswa yang gemar membaca akan dapat 
memperoleh berbagai pengetahuan dan teknologi. Dengan demikian, wawasan akan bertambah luas sehingga akan sangat mempengaruhi peningkatan atau pencapaianprestasi belajar siswa_yang seoptimal mungkin karena siswa yang memiliki minat terhadap sesuatu pelajaran akan mempelajari dengan sungguhsungguh karena ada daya tarik baginya.

$$
\text { Mulyasa }
$$

mendefinisikan bahwa, "efektivitas adalah adanya kesesuaian antara orang yang melaksanakan tugas dengan sasaran yang dituju". Efektivitas adalah bagaimana suatu organisasi berhasil mendapatkan dan memanfaatkan sumber daya dalam usaha mewujudkan tujuan organisasi.

Selanjutnya, untuk mengukur efektivitas pelayanan akademik dalam penelitian ini mengacu pada pendapat Handoko (2003:7), bahwa efektivitas adalah "kemampuan untuk memilih tujuan yang tepat atau peralatan yang tepat untuk mencapai tujuan yang ditetapkan. Berbeda dengan definisi sebelumnya yaitu memilih tujuan yang akan dicapai. Jika alat-alat yang dipilih sesuai dengan tujuan yang ditetapkan, maka akan terjadi akselerasi pencapaian tujuan tersebut", atau secara singkatnya indikator tersebut adalah: (1) Penentuan tujuan; (2) Peralatan yang tepat; dan (3) Hasil kerja sesuai standar yang ditetapkan (Handoko, 2003:7).

Selain guru harus memiliki kualifikasi akademik, guru juga harus memiliki kompetensi yang memenuhi stndar. Kompetensi, menurut Undangundang Nomor 14 Tahun 2005 tentang Guru dan Dosen, adalah seperangkat pengetahuan, keterampilan, dan perilaku yang harus dimiliki, dihayati, dan dikuasai oleh guru atau dosen dalam melaksanakan tugas keprofesionalan.

Sementara itu menurut Gordon, sebagaimana dikutip oleh Mulyasa (2004:38) menjelaskan beberapa aspek atau ranah yang terkandung dalam konsep kompetensi yaitu (1) pengetahuan (knowledge), yaitu kesadaran dalam bidang kognitif, (2) pemahaman (understanding), yaitu kedalaman kognitif, dan afektif yang dimiliki oleh individu, (3) kemampuan (skill) adalah sesuatu yang dimiliki oleh individu untuk melakukan tugas atau pekerjaan yang dibebankan kepadanya, (4) nilai (value), adalah suatu standar perilaku yang telah diyakini dan secara psikologis telah menyatu dalam diri seseorang, (5) sikap (attitude), yaitu perasaan senang-tidak senang, suka-tidak suka atau reaksi terhadap suatu rangsangan yang datang dari luar, dan (6) minat (interest), yaitu kecenderungan seseorang untuk melakukan sesuatu perbuatan.

Suryadi dan Mulyana (2003:21) mengemukakan kompetensi guru bertolak dari analisis tugas-tugas guru baik sebagai pengajar, pembimbing, maupun administrator di dalam kelas. Kompetensi guru terdiri dari: (1) menguasai bahan pelajaran, (2) mengelola program belajar mengajar (3) mengelola kelas, (4) menggunakan media atau sumber belajar, (5) menguasai landasan kependidikan, (6) mengelola interaksi belajar mengajar, (7) menilai prestasi belajar, (8) mengenal fungsi dan layanan bimbingan penyuluhan, (9) mengenal dan menyelenggarakan administrasi sekolah, dan (10) memahami dan menafsirkan hasil penelitian guna keperluan pengajaran.

Depdiknas (2005:9) merumuskan ruang lingkup kompetensi guru ke dalam tiga komponen. Pertama, komponen kompetensi pengelolaan pembelajaran, yang mencakup (1) penyusunan perencanaan pembelajaran, pelaksanaan interaksi belajar mengajar, (3) penilaian prestasi belajar peserta didik, (4) pelaksanaan tindak lanjut hasil penilaian. Kedua, komponen kompetensi pengembangan potensi yang diorientasikan pada pengembangan profesi. Ketiga, kompetensi penguasaan akademik yang mencakup (1) pemahaman wawasan pendidikan, (2) penguasaan bahan kajian akademik. 
Menurut Undang-undang No.14 tahun 2005 tentang Guru Dan Dosen pasal 10 ayat (1) kompetensi guru meliputi kompetensi pedagogik, kompetensi kepribadian, kompetensi sosial, dan kompetensi profesional yang diperoleh melalui pendidikan profesi. Indikator efektifias pelayanan akademik dan kompetensi pedagogik guru terdapat dalam tabel 1 dan tabel 2 pada subbagian selanjutnya.

\section{METODE PENELITIAN}

Metode penelitian merupakan tahapan yang dilakukan dalam melakukan penelitian yang meliputi pengumpulan, penyusunan, analisis, dan interpretasi data yang diperoleh. Sugiyono (2010:3) mengatakan bahwa "metode penelitian merupakan cara ilmiah untuk mendapatkan data dengan tujuan dan kegunaan tertentu. Cara ilmiah berarti kegiatan penelitian itu didasarkan pada ciri-ciri keilmuan, yaitu rasional, empiris dan sistematis.

Rasional berarti kegiatan penelitian itu dilakukan dengan cara-cara yang masuk akal, sehingga terjangkau oleh penalaran manusia, dan mengetahui cara-cara yang digunakan. Sistematis artinya proses yang digunakan dalam penelitian ini menggunakan langkahlangkah tertentu yang bersifat logis." Berdasarkan tujuan yang ingin dicapai dan rumusan masalah, penelitian ini menggunakan pendekatan kuantitatif dengan jenis metode yang digunakan oleh penulis yaitu metode analisis statistik deskriptif.

Tabel 1 : Kisi - Instrumen Variabel Efektifitas Pelayanan Akademik

\begin{tabular}{ccl}
\hline Variabel & Dimensi & \multicolumn{1}{c}{ Indikator } \\
\hline Efektivitas & $\bullet$ Penentuan tujuan & - Penetapan tujuan \\
Pelayanan & & - Target yang jelas \\
Akademik & & - Ketersediaan peralatan \\
$\left(\mathrm{X}_{1}\right)$ & $\bullet$ Peralatan yang tepat & - Perencanaan pembelajaran \\
Handoko & (Instrumen) & - Evaluasi pembelajaran \\
$(2000: 7)$ & & - Proses administratif yang terstandar \\
& - Hasil kerja sesuai & - Dedikasi terhadap pelayanan \\
& - Responsif \\
& standar yang & - Mendukung aspirasi siswa \\
& ditetapkan & - Evaluasi standar \\
\hline
\end{tabular}

Tabel 2 : Kisi - Instrumen Variabel Kompetensi Pedagogik Guru

\begin{tabular}{|c|c|c|}
\hline $\begin{array}{l}\text { Kompetensi } \\
\text { Pedagogik } \\
\text { Guru } \\
\left(\mathrm{X}_{2}\right) \\
\text { (Kunandar, } \\
\text { 2010:76). }\end{array}$ & $\begin{array}{l}\text { - Pemahaman terhadap } \\
\text { peserta didik }\end{array}$ & $\begin{array}{l}\text { - Memahami peserta didik dengan } \\
\text { prinsip kognitif } \\
\text { - Memahami peserta didik dengan } \\
\text { prinsip kepribadian } \\
\text { - Mengidentifikasi bekal ajar awal } \\
\text { peserta didik }\end{array}$ \\
\hline & $\begin{array}{l}\text { - Perancangan } \\
\text { pembelajaran }\end{array}$ & $\begin{array}{l}\text { - Menerapkan } \\
\text { belajar/pembelajaran } \\
\text { - Menentukan } \\
\text { pembelajaran }\end{array}$ \\
\hline
\end{tabular}


- Pelaksanaan pembelajaran

- Evaluasi hasil belajar

- Pengembangan peserta didik
- Menyusun rancangan pembelajaran berdasarkan strategi yang dipilih

- Menata latar (setting) pembelajaran

- Melaksanakan pembelajaran yang kondusif

- Merancang evaluasi proses pembelajaran

- Melaksanakan evaluasi proses dan hasil belajar

- Memanfaatkan hasil penilaian pembelajaran untuk perbaikan kualitas

- Memfasiliasi peserta didik untuk pengembangan potensi akademik

- Memfasilitasi peserta didik untuk menembangkan potensi nonakademik

Tabel 3 : Kisi - Instrumen Variabel Minat Belajar Siswa

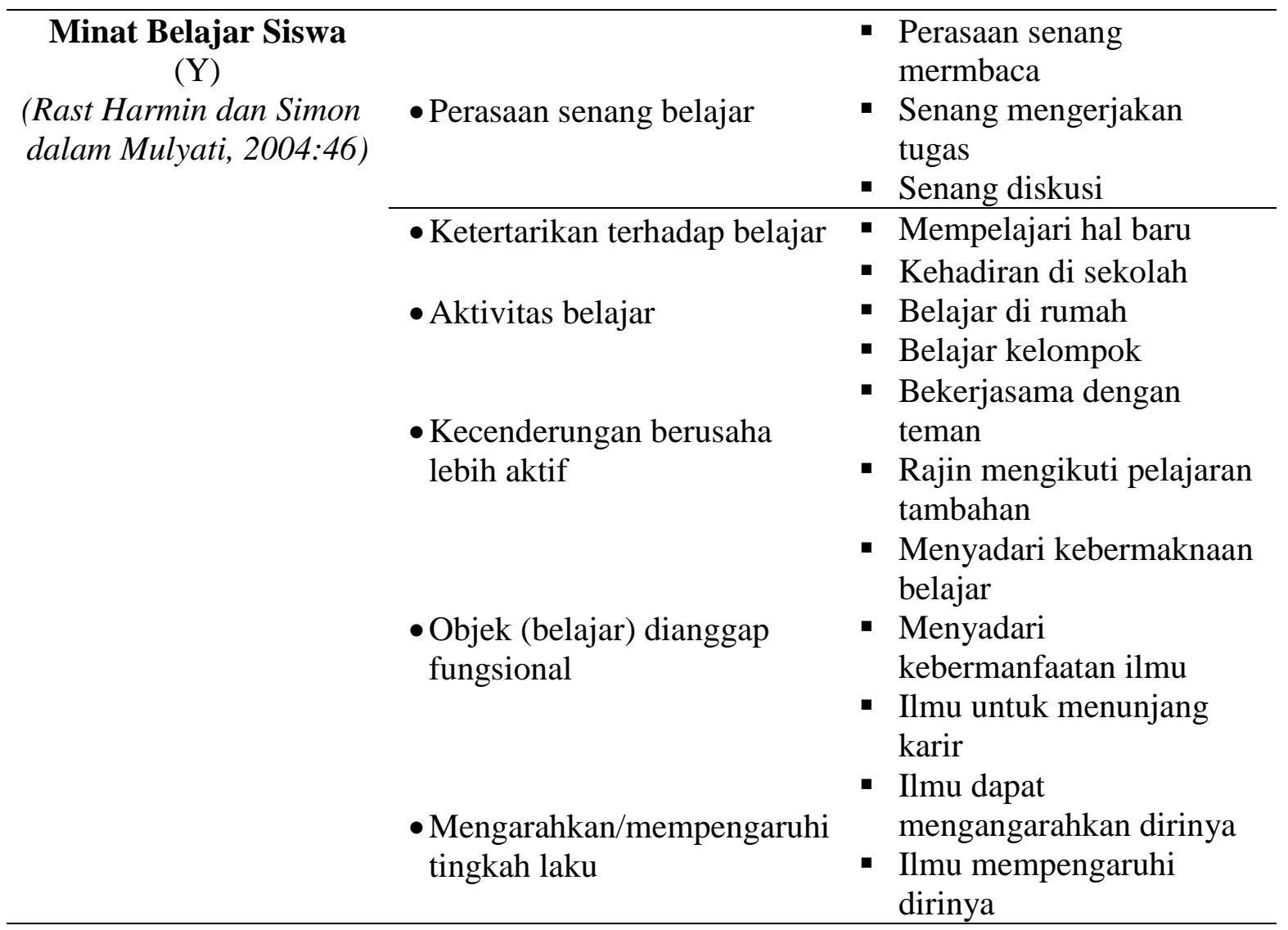


PEMBAHASAN HASIL PENELITIAN

Fokus utama pada penelitian ini adalah untuk mengetahui besaran pengaruh efektivitas pelayanan akademik dan kopetensi pedagogic guru terhadap minat bealajar siswa sekolah menengah pertama negeri di kecamatan jatibarang kabupaten indramayu.

Untuk mengetahui besarnya pengaruh efektivitas pelayanan akademik
$\left(\mathrm{X}_{1}\right)$ secara individual (parsial) terhadap minat belajar siswa $(\mathrm{Y})$ dapat dilihat dari nilai t pada tabel Coefficients dibawah ini dengan kriteria pengujian jika tingkat signifikansi lebih kecil dari 0,05, maka hipotesis diterima. Adapun hasil pengujian hipotesis tersebut adalah sebagai berikut:

Tabel 4. Uji Hipotesis ( $t$ ) Variabel $X_{1}$ terhadap $Y$ Coefficients $^{\text {a }}$

\begin{tabular}{|c|c|c|c|c|c|c|}
\hline & \multirow[t]{2}{*}{ Model } & \multicolumn{2}{|c|}{$\begin{array}{c}\text { Unstandardized } \\
\text { Coefficients }\end{array}$} & \multirow{2}{*}{$\begin{array}{l}\text { Standardized } \\
\text { Coefficients }\end{array}$} & \multirow[t]{2}{*}{$\mathrm{T}$} & \multirow[t]{2}{*}{ Sig. } \\
\hline \multirow{3}{*}{1} & & $\mathrm{~B}$ & Std. Error & & & \\
\hline & (Constant) & 15.336 & 7.928 & & 1.934 & .059 \\
\hline & $\begin{array}{l}\text { Efektivitas_pelayanan } \\
\text { X1 }\end{array}$ & .809 & .106 & .734 & 7.650 & .000 \\
\hline
\end{tabular}

a. Dependent Variable: Minat_Belajar_Siswa_Y

Berdasarkan tabel hasil uji $\mathrm{t}$ diperoleh bahwa nilai thitung variabel efektivitas pelayanan akademik $\left(\mathrm{X}_{1}\right)$ memiliki nilai sebesar $p$-value 0,000 $<\quad 0,05$ artinya berdistribusi signifikan. Hal tersebut berarti efektivitas pelayanan akademik $\left(\mathrm{X}_{1}\right)$ secara parsial berpengaruh terhadap minat belajar siswa (Y). Hal tersebut berarti menerima hipotesis yang menyatakan : "Terdapat pengaruh positif dan signifikan efektivitas pelayanan akademik terhadap minat belajar siswa SMP Negeri di
Kecamatan Jatibarang Kabupaten Indramayu ".

Persamaan regresi $\mathrm{y}=\mathrm{a} \mathrm{bx}_{1}$ dari hasil perhitungan diperoleh $\mathrm{y}=$ $15,336+0,809 \mathrm{x}_{1}$. Konstanta sebesar 15,809 menyatakan bahwa jika ada kenaikan nilai dari variabel efektivitas pelayanan akademik $\left(\mathrm{X}_{1}\right)$, maka minat belajar siswa (Y) adalah 15,809. Koefesien regresi sebesar 0,809 menyatakan bahwa setiap perubahan satu skor atau nilai efektivitas pelayanan akademik akan memberikan skor 0,809 .

Tabel 5. Signifikansi Pengaruh Variabel $X_{1}$ terhadap $Y$

ANOVA $^{\mathrm{a}}$

\begin{tabular}{|c|c|c|c|c|c|c|}
\hline Mode & & $\begin{array}{l}\text { Sum of } \\
\text { Squares }\end{array}$ & df & Mean Square & $\mathrm{F}$ & Sig. \\
\hline 1 & $\begin{array}{l}\text { Regressio } \\
n\end{array}$ & 4638.892 & 1 & 4638.892 & 58.530 & $.000^{\mathrm{b}}$ \\
\hline & Residual & 3962.858 & 50 & 79.257 & & \\
\hline & Total & 8601.750 & 51 & & & \\
\hline
\end{tabular}

a. Dependent Variable: Minat_Belajar_Siswa_Y

b. Predictors: (Constant), Efektivitas_pelayanan_X1 
Berdasarkan tabel hasil uji anova atau $F$ test didapat $F_{\text {hitung }}$ sebesar 58,530 dan nilai signifikansi $0,000<0,05$. Dengan demikian $\mathrm{H}_{\mathrm{o}}$ ditolak artinya pengaruh efektivitas pelayanan akademik terhadap minat belajar siswa SMP Negeri di Kecamatan Jatibarang Kabupaten Indramayu adalah signifikan. Menurut Handoko (2000:7) mengemukakan bahwa efektivitas adalah kemampuan untuk memilih tujuan yang tepat atau peralatan yang tepat untuk mencapai tujuan yang ditetapkan. Berbeda dengan definisi sebelumnya yaitu memilih tujuan yang akan dicapai. Jika alat-alat yang dipilih sesuai dengan tujuan yang ditetapkan, maka akan terjadi akselerasi pencapaian tujuan tersebut. Sehingga dihubungkan dengan suatu aktivitas untuk mencapai tujuan tertentu.Selanjutnya untuk mengetahui seberapa besar pengaruh efektivitas pelayanan akademik terhadap minat belajar siswa dapat dilihat dari hasil perhitungan koefesien determinasi pada tabel dibawah ini:

\section{Tabel 6. Besaran Pengaruh Variabel $\mathrm{X}_{1}$ terhadap $\mathrm{Y}$ Model Summary}

\begin{tabular}{|c|c|c|c|c|}
\hline \multirow[b]{2}{*}{ Model } & \multicolumn{4}{|c|}{ Adjusted R } \\
\hline & $\mathrm{R}$ & R Square & Square & Std. Error of the Estimate \\
\hline 1 & $.734^{\mathrm{a}}$ & .539 & .530 & 8.903 \\
\hline
\end{tabular}

a. Predictors: (Constant), Efektivitas_pelayanan_X1

Dari tabel di atas terlihat bahwa $R$ Square sebesar 0,539, hal ini berarti bahwa $0,539 \times 100 \%=53,9 \%$ minat belajar siswa dipengaruhi oleh variabel efektivitas pelayanan akademik, sedangkan sisanya 46,1\% dipengaruhi oleh faktor lain yang tidak diteliti.

Untuk mengetahui besaran pengaruh kompetensi pedagogik guru $\left(\mathrm{X}_{2}\right)$ secara individual (parsial) terhadap minat belajar siswa (Y) dapat dilihat dari nilai t pada tabel Coefficients dibawah ini dengan kriteria pengujian jika tingkat signifikansi lebih kecil dari 0,05 , maka hipotesis diterima. Adapun hasil pengujian hipotesis tersebut adalah sebagai berikut:

Tabel 7. Uji Hipotesis ( $t$ ) Variabel $X_{2}$ terhadap $Y$ Coefficients $^{\mathrm{a}}$

\begin{tabular}{rlrrrrr}
\hline \multicolumn{1}{c}{ Model } & \multicolumn{2}{c}{$\begin{array}{c}\text { Unstandardized } \\
\text { Coefficients }\end{array}$} & $\begin{array}{l}\text { Standardized } \\
\text { Coefficients }\end{array}$ & \multicolumn{1}{c}{ t } & Sig. \\
\hline \multirow{2}{*}{1} & \multicolumn{1}{c}{ B } & Std. Error & Beta & & \\
& $\begin{array}{l}\text { (Constant) } \\
\text { Kompetensi_Peda } \\
\text { gogik_X2 }\end{array}$ & 28.831 & 6.761 & & 4.264 & .000 \\
& .671 & .096 & .703 & 6.995 & .000 \\
\hline
\end{tabular}

a. Dependent Variable: Minat_Belajar_Siswa_Y 
Berdasarkan tabel hasil uji $\mathrm{t}$ diperoleh bahwa nilai thitung variabel kompetensi pedagogik guru $\left(\mathrm{X}_{2}\right)$ memiliki nilai sebesar p-value 0,000 $<0,05$ artinya signifikan. Dengan demikian kompetensi pedagogik guru $\left(\mathrm{X}_{2}\right)$ secara parsial berpengaruh terhadap minat belajar siswa (Y). Hal tersebut mengandung makna diterimanya hipotesis yang menyatakan: "Terdapat pengaruh positif dan signifikan kompetensi pedagogik guru terhadap minat belajar siswa SMP Negeri di
Kecamatan Jatibarang Kabupaten Indramayu ".

Persamaan regresi $\mathrm{y}=\mathrm{a} \mathrm{bx}_{2}$ dari hasil perhitungan diperoleh $\mathrm{y}=$ $28,831+0,671 x_{2}$. Konstanta sebesar 28,831 menyatakan bahwa jika ada kenaikan nilai dari variabel kompetensi pedagogik guru $\left(\mathrm{X}_{2}\right)$, maka minat belajar siswa (Y) adalah 28,831. Koefesien regresi sebesar 0,671 menyatakan bahwa setiap perubahan satu skor atau kompetensi pedagogik guru akan memberikan skor 0,671 .

Tabel 8. Pengaruh Variabel $X_{2}$ terhadap $Y$

ANOVA ${ }^{a}$

\begin{tabular}{crrrrrr}
\hline & & & \multicolumn{4}{c}{ Mean } \\
Model & & Sum of Squares & df & Square & \multicolumn{1}{c}{ F } & Sig. \\
\hline 1 & Regression & 4254.319 & 1 & 4254.31 & 48.92 & \\
& & 4347.431 & 50 & 86.949 & & \\
& Residual & 8601.750 & 51 & & & \\
& Total & & & & & \\
\end{tabular}

a. Dependent Variable: Minat_Belajar_Siswa_Y

b. Predictors: (Constant), Kompetensi_Pedagogik_X2

Berdasarkan tabel hasil uji anova atau $\mathrm{F}$ test didapat $\mathrm{F}_{\text {hitung }}$ sebesar 48,929 dan signifikansi 0,000 $<0,05$ sehingga $\mathrm{H}_{\mathrm{o}}$ ditolak artinya pengaruh kompetensi pedagogik guru terhadap minat belajar siswa SMP Negeri di Kecamatan Jatibarang Kabupaten Indramayu adalah signifikan. Untuk menyatakan bahwa suatu kegiatan belajar mengajar dikatakan bermutu, dapat diketahui dari tingkat keberhasilan kegiatan belajar mengajar tersebut dalam mencapai tujuan instruksional khusus (Djamarah \& Zain, 2002:12). Lebih lanjut Djamarah \& Zain mengemukakan yang menjadi petunjuk bahwa kegiatan belajar mengajar dianggap berhasil adalah: (a) daya serap terhadap bahan pengajaran yang diajarkan mencapai prestasi tinggi baik secara individu maupun kelompok, (b) perilaku yang digariskan dalam tujuan instruksional khusus (TIK) telah dicapai siswa baik individu maupu kelompok.

Selanjutnya Djamarah \& Zain (2002:36) mengungkapkan bahwa "untuk meningkatkan hasil belajar dalam bentuk pengaruh instruksional dan untuk mengarahkan pengaruh pengiring terhadap hal-hal yang positif dan berguna untuk siswa, guru harus pandai memilih apa isi 
pengajaran sera bagaimana proses belajar tersebut harus dikelola dan dilaksanakan di sekolah". Selanjutnya untuk mengetahui seberapa besar pengaruh kompetensi pedagogik guru terhadap minat belajar siswa dapat dilihat dari hasil perhitungan koefesien determinasi pada tabel dibawah ini:

Tabel 9. Besaran Pengaruh Variabel $X_{2}$ terhadap $Y$ Model Summary

\begin{tabular}{ccrrr}
\hline Model & R & R Square & $\begin{array}{c}\text { Adjusted R } \\
\text { Square }\end{array}$ & \multicolumn{2}{c}{$\begin{array}{c}\text { Std. Error of } \\
\text { the Estimate }\end{array}$} \\
\hline 1 & $.703^{\text {a }}$ & .495 & .484 & 9.325 \\
\hline
\end{tabular}

a. Predictors: (Constant), Kompetensi_Pedagogik_X2

Dari tabel di atas terlihat bahwa $R$ Square sebesar 0,495 , hal ini berarti bahwa $0,495 \times 100 \%=49,5 \%$ minat belajar siswa dipengaruhi oleh variabel kompetensi pedagogic guru, sedangkan sisanya $50,5 \%$ dipengaruhi oleh faktor lain yang tidak diteliti.

Untuk mengetahui besaran pengaruh efektivitas pelayanan akademik $\left(\mathrm{X}_{1}\right)$ dan kompetensi pedagogik guru secara bersama-sama (ganda) terhadap minat belajar siswa (Y) dapat dilihat dari nilai t pada tabel Coefficients dibawah ini dengan kriteria pengujian jika tingkat signifikansi lebih kecil dari 0,05, maka hipotesis diterima. Adapun hasil pengujian hipotesis tersebut adalah sebagai berikut:

Tabel 10. Uji Hipotesis ( $t$ ) Variabel $X_{1}$ dan $X_{2}$ terhadap $Y$ Coefficients $^{\mathbf{a}}$

\begin{tabular}{|c|c|c|c|c|c|c|}
\hline & Model & $\begin{array}{r}\text { Unsta } \\
\text { Coe }\end{array}$ & $\begin{array}{l}\text { dardized } \\
\text { icients }\end{array}$ & $\begin{array}{l}\text { Standardi } \\
\text { zed } \\
\text { Coefficien } \\
\text { ts } \\
\end{array}$ & \multirow[t]{2}{*}{$\mathrm{t}$} & \multirow[t]{2}{*}{ Sig. } \\
\hline \multirow{4}{*}{1} & & B & Std. Error & Beta & & \\
\hline & (Constant) & 13.335 & 7.539 & & 1.769 & .083 \\
\hline & $\begin{array}{l}\text { Efektivitas_pelayan } \\
\text { an_X1 }\end{array}$ & .521 & .149 & .473 & 3.505 & .001 \\
\hline & $\begin{array}{l}\text { Kompetensi_Pedago } \\
\text { gik_X2 }\end{array}$ & .337 & .129 & .353 & 2.620 & .012 \\
\hline
\end{tabular}

a. Dependent Variable: Minat_Belajar_Siswa_Y

Berdasarkan tabel hasil uji $\mathrm{t}$ diperoleh bahwa nilai $t_{\text {hitung }}$ variabel efektivitas pelayanan akademik $\left(\mathrm{X}_{1}\right)$ dan kompetensi pedagogik guru $\left(\mathrm{X}_{2}\right)$ secara bersama-sama (simultan) memiliki nilai sebesar p-value 0,001 $<0,05$ artinya signifikan. Dengan demikian efektivitas pelayanan akademik $\left(\mathrm{X}_{1}\right)$ dan kompetensi 
pedagogik guru $\left(\mathrm{X}_{2}\right)$ secara bersamasama (simultan) berpengaruh terhadap minat belajar siswa (Y). Hal tersebut membuktikan diterimanya hipotesis yang menyatakan: "Terdapat pengaruh positif dan signifikan efektivitas pelayanan akademik dan kompetensi pedagogik guru secara bersama-sama terhadap minat belajar siswa SMP Negeri di Kecamatan Jatibarang Kabupaten Indramayu ".

Untuk mengetahui persamaan regresi dapat dilihat dari tabel di atas. Berdasarkan tabel tersebut menunjukkan persamaan regresi linier ganda:

$$
\begin{aligned}
& \hat{Y}=13,335+0,521 X 1+0,337 X 2 \\
& \text { Persamaan tersebut } \\
& \text { menyatakan bahwa setiap } \\
& \text { penambahan } \mathrm{X}_{1} \text { dan } \mathrm{X}_{2} \text { sebesar } 1
\end{aligned}
$$

Tabel 11. Signifikansi Pengaruh Variabel $X_{1}$ dan $X_{2}$ terhadap $Y$ ANOVA ${ }^{a}$

\begin{tabular}{lllrrrr}
\hline \multirow{2}{*}{ Model } & Sum of & & Mean & & \\
& & Squares & df & Square & F & Sig. \\
\hline 1 & Regression & 5125.743 & 2 & 2562.8 & 36.128 & $.000^{\mathrm{b}}$ \\
& & & & 71 & & \\
& Residual & 3476.007 & 49 & 70.939 & & \\
& Total & 8601.750 & 51 & & & \\
\hline
\end{tabular}

a. Dependent Variable: Minat_Belajar_Siswa_Y

b. Predictors: (Constant), Kompetensi_Pedagogik_X2,

Efektivitas_pelayanan_X1

Berdasarkan tabel hasil uji anova atau $\mathrm{F}$ test didapat $\mathrm{F}_{\text {hitung }}$ sebesar 36,128 dan signifikansi 0,000 $<0,05$ sehingga $\mathrm{H}_{\mathrm{o}}$ ditolak artinya pengaruh efektivitas pelayanan akademik dan kompetensi pedagogik guru secara bersama-sama terhadap minat belajar siswa SMP Negeri di Kecamatan Jatibarang Kabupaten Indramayu adalah signifikan.
Selanjutnya untuk mengetahui seberapa besar pengaruh efektivitas pelayanan akademik dan kompetensi pedagogik guru secara simultan terhadap minat belajar siswa dapat dilihat dari hasil perhitungan koefesien determinasi pada tabel dibawah ini: 
Tabel 12. Besaran Pengaruh Variabel $X_{1}$ dan $X_{2}$ terhadap $Y$ Model Summary

\begin{tabular}{ccrrr}
\hline Model & R & R Square & \multicolumn{1}{c}{$\begin{array}{c}\text { Adjusted R } \\
\text { Square }\end{array}$} & $\begin{array}{l}\text { Std. Error of } \\
\text { the Estimate }\end{array}$ \\
\hline 1 & $.772^{\mathrm{a}}$ & .596 & .579 & 8.423 \\
\hline
\end{tabular}

a. Predictors: (Constant), Kompetensi_Pedagogik_X2,

Efektivitas_pelayanan_X1

Dari tabel di atas terlihat bahwa $R$ Square sebesar 0,596 , hal ini berarti bahwa $0,596 \times 100 \%=59,6 \%$ minat belajar siswa dipengaruhi oleh variabel efektivitas pelayanan akademik dan kompetensi pedagogik guru secara simultan, sedangkan sisanya 40,4\% dipengaruhi faktor lain yang tidak diteliti.

Permasalahan yang ingin dijawab dalam penelitian ini adalah adakah pengaruh efektivitas pelayanan akademik terhadap minat belajar siswa SMP Negeri di Kecamatan Jatibarang Kabupaten Indramayu. Secara empirik, hasil penelitian ini menginformasikan: (1) terdapat pengaruh positif dan signifikan antara efektivitas pelayanan akademik terhadap minat belajar siswa SMP Negeri di Kecamatan Jatibarang Kabupaten Indramayu, serta (2) besarnya kontribusi efektivitas pelayanan akademik terhadap minat belajar siswa SMP Negeri di Kecamatan Jatibarang Kabupaten Indramayu ditunjukkan oleh hasil penelitian bahwa efektivitas pelayanan akademik yang terdiri dari dimensi: 1) Penentuan tujuan; 2) Peralatan yang tepat; dan 3) Hasil kerja sesuai standar yang ditetapkan (Handoko (2000:7), membawa implikasi yang signifikan terhadap minat belajar siswa yang meliputi dimensi:
Perasaan senang belajar; (2) Ketertarikan terhadap belajar; (3) Aktivitas belajar; (4) Kecenderungan berusaha lebih aktif; (5) Objek (belajar) dianggap fungsional; dan (6) Mengarahkan/mempengaruhi tingkah laku (Rast Harmin dan Simon dalam Mulyati, 2004:46).

Namun demikian minat belajar siswa SMP Negeri di Kecamatan Jatibarang Kabupaten Indramayu ini tidak hanya dipengaruhi oleh efektivitas pelayanan akademik saja, ada faktor lain (epsilon), selain dari supervisi akademik, yang juga berpengaruh, yang tidak dikaji dalam penelitian ini. Dengan demikian, hasil penelitian ini mengindikasikan bahwa semakin tinggi efektivitas pelayanan akademik pada SMP Negeri di Kecamatan Jatibarang Kabupaten Indramayu, maka akan diikuti oleh semakin tingginya minat belajar siswa. Hal ini dapat diterangkan oleh persamaan regresi $\mathrm{y}=15,336+0,809 \mathrm{x}_{1}$. Dengan persamaan regresi tersebut dapat diinterpretasikan bahwa jika efektivitas pelayanan akademik $\left(\mathrm{X}_{1}\right)$ dan minat belajar siswa (Y) diukur dengan instrumen yang dikembangkan dalam penelitian ini, maka setiap perubahan skor efektivitas pelayanan akademik sebesar satu satuan dapat diestimasikan skor minat belajar 
siswa akan berubah 0,809 satuan pada arah yang sama.

Berdasarkan temuan empirik yang menunjukkan adanya pengaruh yang signifikan efektivitas pelayanan akademik dengan minat belajar siswa, maka hasil penelitian ini memberikan beberapa informasi, di antaranya: (1) efektivitas pelayanan akademik pada SMP Negeri di Kecamatan Jatibarang Kabupaten Indramayu memberikan kontribusi yang berarti terhadap minat belajar siswa, (2) salah satu cara untuk meningkatkan minat belajar siswa SMP Negeri di Kecamatan Jatibarang Kabupaten Indramayu adalah dengan meningkatkan efektivitas pelayanan akademik, serta (3) persentase kontribusi efektivitas pelayanan akademik terhadap minat belajar siswa adalah sebesar 53,9\%, sementara sisanya dipengaruhi oleh variabel lain, selain variabel kompetensi pedagogik guru, yang tidak dikaji dalam penelitian ini (epsilon).

Permasalahan yang ingin dijawab dalam penelitian ini adalah adakah pengaruh kompetensi pedagogik guru terhadap minat belajar siswa SMP Negeri di Kecamatan Jatibarang Kabupaten Indramayu. Secara empirik, hasil penelitian ini menginformasikan: (1) terdapat pengaruh positif dan signifikan antara kompetensi pedagogik guru terhadap minat belajar siswa SMP Negeri di Kecamatan Jatibarang Kabupaten Indramayu, serta (2) besarnya kontribusi kompetensi pedagogik guru terhadap minat belajar siswa SMP Negeri di Kecamatan Jatibarang Kabupaten Indramayu ditunjukkan oleh hasil penelitian bahwa kompetensi pedagogik guru yang terdiri dari dimensi: (1) Pemahaman terhadap peserta didik; (2) Perancangan pembelajaran; (3) Pelaksanaan pembelajaran; (4) Evaluasi hasil belajar; dan (5) Pengembangan peserta didik (Kunandar, 2010:76), membawa implikasi yang signifikan terhadap minat belajar siswa yang meliputi dimensi: (1) Perasaan senang belajar; (2) Ketertarikan terhadap belajar; (3) Aktivitas belajar; (4) Kecenderungan berusaha lebih aktif; (5) Objek (belajar) dianggap fungsional; dan (6) Mengarahkan/mempengaruhi tingkah laku (Rast Harmin dan Simon dalam Mulyati, 2004:46). Namun demikian minat belajar siswa SMP Negeri di Kecamatan Jatibarang Kabupaten Indramayu ini tidak hanya dipengaruhi oleh kompetensi pedagogik gurusaja, ada faktor lain (epsilon), selain dari efektivitas pelayanan akademik, yang juga berpengaruh, yang tidak dikaji dalam penelitian ini.

Dengan demikian, hasil penelitian ini mengindikasikan bahwa semakin tinggi kompetensi pedagogik guru SMP Negeri di Kecamatan Jatibarang Kabupaten Indramayu, maka akan diikuti oleh semakin tingginya minat belajar siswa. Hal ini dapat diterangkan oleh persamaan regresi $\quad \mathrm{y}=28,831+0,671 \mathrm{X}_{2}$. Dengan persamaan regresi tersebut dapat diinterpretasikan bahwa jika kompetensi pedagogik guru $\left(\mathrm{X}_{2}\right)$ dan minat belajar siswa (Y) diukur dengan instrumen yang dikembangkan dalam penelitian ini, maka setiap perubahan skor minat belajar siswa sebesar satu satuan dapat diestimasikan skor minat belajar siswa akan berubah 0,671 satuan pada arah yang sama. 
Berdasarkan temuan empirik yang menunjukkan adanya pengaruh yang signifikan kompetensi pedagogik guru terhadap minat belajar siswa, maka hasil penelitian ini memberikan beberapa informasi, di antaranya: (1) kompetensi pedagogik guru SMP Negeri di Kecamatan Jatibarang Kabupaten Indramayu memberikan pengaruh yang berarti terhadap minat belajar siswa, (2) salah satu cara untuk meningkatkan minat belajar siswa SMP Negeri di Kecamatan Jatibarang Kabupaten Indramayu adalah dengan meningkatkan kompetensi pedagogik guru, serta (3) persentase pengaruh kompetensi pedagogik guru terhadap minat belajar siswa adalah sebesar 49,5\%, sementara sisanya dipengaruhi oleh variabel lain, selain variabel efektivitas pelayanan akademik, yang tidak dikaji dalam penelitian ini (epsilon).

Permasalahan yang ingin dijawab dalam penelitian ini adalah adakah pengaruh efektivitas pelayanan akademik, dan kompetensi pedagogik guru secara bersama-sama (simultan) terhadap minat belajar siswa SMP Negeri di Kecamatan Jatibarang Kabupaten Indramayu. Secara empirik, hasil penelitian ini menginformasikan: (1) terdapat pengaruh positif dan signifikan antara efektivitas pelayanan akademik dan kompetensi pedagogik guru secara bersama-sama terhadap minat belajar siswa SMP Negeri di Kecamatan Jatibarang Kabupaten Indramayu, serta (2) besaran pengaruh efektivitas pelayanan akademik dan kompetensi pedagogik guru terhadap minat belajar siswa SMP Negeri di Kecamatan Jatibarang Kabupaten Indramayu ditunjukkan oleh hasil penelitian bahwa efektivitas pelayanan akademik yang terdiri dari dimensi: 1) Penentuan tujuan; 2) Peralatan yang tepat; dan 3) Hasil kerja sesuai standar yang ditetapkan (Handoko (2000:7), serta kompetensi pedagogik guru yang terdiri atas dimensi: (1) Pemahaman terhadap peserta didik; (2) Perancangan pembelajaran; (3) Pelaksanaan pembelajaran; (4) Evaluasi hasil belajar; dan (5) Pengembangan peserta didik (Kunandar, 2010:76), membawa implikasi yang signifikan terhadap minat belajar siswa yang meliputi dimensi: (1) Perasaan senang belajar; (2) Ketertarikan terhadap belajar; (3) Aktivitas belajar; (4) Kecenderungan berusaha lebih aktif; (5) Objek (belajar) dianggap fungsional; dan (6) Mengarahkan/mempengaruhi tingkah laku (Rast Harmin dan Simon dalam Mulyati, 2004:46).

Namun demikian minat belajar siswa SMP Negeri di Kecamatan Jatibarang Kabupaten Indramayu ini tidak hanya dipengaruhi oleh efektivitas pelayanan akademik, dan kompetensi pedagogik guru saja, ada faktor lain (epsilon), yang juga berpengaruh, yang tidak dikaji dalam penelitian ini. Dengan demikian, hasil penelitian ini mengindikasikan bahwa semakin baik efektivitas pelayanan akademik, dan semakin tinggi kompetensi pedagogik guru SMP Negeri di Kecamatan Jatibarang Kabupaten Indramayu, maka akan diikuti oleh semakin tingginya minat belajar siswa. Hal ini dapat diterangkan oleh persamaan regresi:

$$
\begin{array}{r}
\widehat{Y}=13,335+0,521 X 1+0,337 X 2 \\
\text { Dengan persamaan regresi } \\
\text { tersebut dapat diinterpretasikan }
\end{array}
$$


bahwa jika efektivitas pelayanan akademik $\quad\left(\mathrm{X}_{1}\right), \quad$ kompetensi pedagogik guru $\left(\mathrm{X}_{2}\right)$ dan minat belajar siswa (Y) diukur dengan instrumen yang dikembangkan dalam penelitian ini, maka setiap perubahan skor efektivitas pelayanan akademik dan kompetensi pedagogik guru sebesar satu satuan dapat diestimasikan skor minat belajar siswa akan berubah 0,521 dan 0,337 satuan pada arah yang sama.

Berdasarkan temuan empirik yang menunjukkan adanya pengaruh yang signifikan efektivitas pelayanan akademik, dan kompetensi pedagogik guru terhadap minat belajar siswa, maka hasil penelitian ini memberikan beberapa informasi, di antaranya: (1) efektivitas pelayanan akademik, dan kompetensi pedagogik guru SMP Negeri di Kecamatan Jatibarang Kabupaten Indramayu memberikan pengaruh yang berarti terhadap minat belajar siswa, (2) salah satu cara untuk meningkatkan minat belajar siswa SMP Negeri di Kecamatan Jatibarang Kabupaten Indramayu adalah dengan meningkatkan efektivitas pelayanan akademik dan kompetensi pedagogik guru. (3) persentase kontribusi yang diberikan oleh efektivitas pelayanan akademik dan kompetensi pedagogik guru secara bersama-sama terhadap minat belajar siswa adalah sebesar 59,6\%, sementara sisanya dipengaruhi oleh variabel lain, yang tidak dikaji dalam penelitian ini (epsilon).

\section{DAFTAR PUSTAKA}

Ali Imran. (1996). Belajar dan Pembelajaran. Jakarta: PT Dunia Pustaka Jaya

Depdiknas (2005), Peraturan Pemerintah Republik Indonesia Nomor 19 Tahun 2005 tentang Standar Nasional Pendidikan

Depdiknas (2005), Undang-undang Republik Indonesia Nomor 14 Tahun 2005 tentang Guru dan Dosen

Djamarah \& Zain. (2002). Strategi Belajar Mengajar. Jakarta: PT. Rineka Cipta.

Handoko, T. Hani (2003), Manajemen Personalia dan Sumber Daya Manusia. Yogyakarta: Liberty.

Kunandar. (2010). Guru Profesional: Implementasi KTSP dan Sukses dalam Sertifikasi Guru. Jakarta: Rajawali Press.

Mulyasa, E. (2003). Menjadi Kepala Sekolah Profesional. Bandung: PT Remaja Rosdakarya.

Mulyasa, E. (2004), Menjadi Guru Profesional. Bandung: Remaja Rosdakarya

Mulyati. (2004). Psikologi Belajar. Yogyakarta: Andi Publisher

Slameto. (2003). Belajar dan Faktor-faktor yang Mempengaruhinya. Jakarta: Bina Aksara.

Sugiyono (2010), Metode Penelitian Administrasi, Bandung: Alfabeta

Suryadi dan Mulyana. (2003). Kerangka Konseptual Mutu Pendidikan dan Pembinaan Kemampuan Profesional Guru. Jakarta: Candimas Metropole. 